University of Nebraska - Lincoln

DigitalCommons@University of Nebraska - Lincoln

$5-8-2020$

\title{
Alternatives to High Nebraska Agricultural Land Real Estate Taxes, Part 1 of 2: Capital Gains and Alternative Investments
}

Austin Duerfeldt

University of Nebraska-Lincoln, aduerfeldt2@unl.edu

Follow this and additional works at: https://digitalcommons.unl.edu/ageconfarmmgmt

Part of the Agribusiness Commons, Agriculture Law Commons, Entrepreneurial and Small Business Operations Commons, Management Information Systems Commons, Other Business Commons, Other Economics Commons, and the Taxation-State and Local Commons

Duerfeldt, Austin, "Alternatives to High Nebraska Agricultural Land Real Estate Taxes, Part 1 of 2: Capital Gains and Alternative Investments" (2020). Extension Farm and Ranch Management. 33. https://digitalcommons.unl.edu/ageconfarmmgmt/33

This News Article is brought to you for free and open access by the Agricultural Economics Department at DigitalCommons@University of Nebraska - Lincoln. It has been accepted for inclusion in Extension Farm and Ranch Management by an authorized administrator of DigitalCommons@University of Nebraska - Lincoln. 


\section{Alternatives to High Nebraska Agricultural Land Real Estate Taxes: Part 1 of 2}

\section{By Austin Duerfeldt}

May 8, 2020

In Nebraska, most of my conversations about managing agricultural properties, whether rental or production, tend to steer toward real estate taxes at some point. While many counties in Nebraska have seen agricultural land taxes drop slightly since the 2015-2017 period, they are still a significant portion of operational expense. For example, dryland acres in Southeast Nebraska ballpark around $\$ 60$ an acre. For someone looking to cash rent inherited ground, this becomes a major point of concern when looking for a tenant. If that ground cash rents for $\$ 190$ an acre, and $\$ 60$ an acre goes towards real estate taxes, that leaves us with $\$ 130$ an acre. Looking at an 80 -acre farm, that's $\$ 4,800$ in real estate taxes, leaving you with $\$ 10,400$. Then you still have to account for state and federal income taxes and managing/operational expenses. Suppose you ended with a net income of $\$ 8,000$. If ground is selling for $\$ 6,500$, that puts a total worth of the farm at $\$ 520,000$, giving us a return on asset of $2 \%$ for the rental activity. The question I propose to some is if agricultural land is the best investment for their portfolio?

\section{Capital Gains Tax}

Capital gains tax, as of the time of this article, follows one of two methods. Both methods can be found and studied in IRS Publication 544, Sales and Other Dispositions of Assets. For most assets held for more than a year, the rate is either $0 \%$ for incomes $\$ 0$ to $\$ 39,375$; $15 \%$ for incomes $\$ 39,376$ to $\$ 434,550$; or $20 \%$ for incomes $\$ 434,551$ or more. The rate for assets held for less than a year corresponds to your ordinary income tax bracket $(10 \%, 12 \%, 22 \%, 24 \%, 32 \%, 35 \%$, or $37 \%$.) The rate is applied to the difference between the selling price and the basis, price attributed to the asset at time of original ownership. So, if the above property was purchased in 1992 for $\$ 3,000$ an acre, we would have a capital gain of $\$ 3,500$ an acre, $(6,500-3,000)$, to calculate the tax on. If we are looking at an income of $\$ 80,000$, then that places us in the $15 \%$ tax bracket. $\$ 3,500$ an acre times 80 acres times $15 \%$ gives us a capital gains tax of $\$ 42,000$.

\section{Alternative investing}

Now that the capital gains tax is calculated and paid, we have an amount available for alternative investing. We have $\$ 478,000$ that we can invest to restructure our investing portfolio. One option would be to invest in stock markets. An estimate of rate of returns would be $5 \%-6 \%$. The average annualized total return for the S\&P 500 index over the past 90 years is $9.8 \%$. Taking the $\$ 478,000$ and estimating a $5 \%$ return would give us $\$ 23,900$ a year. Some of that return is represented by unrealized growth in the stock value, which loops us back to the final point.

\section{Consideration for keeping the farmland}

There is one major piece to consider for keeping farmland that is not mentioned so far. The cash rent activity on the farm ground is similar to a divided for stocks. What about accounting for the increase in value of land? Farm ground in the 1960s could be purchased for $\$ 130$ an acre. Now, that same ground is $\$ 6,500$ an acre. Over that 60 -year span, that annualized return on investment was $6.74 \%$. That brings the farmland to a competitive value in comparison to investment like stocks. There will be instances with 
farmland that require major cash outflows to maintain its value and rent ability. Terraces, fence, ditches, soil profiles and other factors not only effect the overall asset value, but could hurt cash rent values as well. Just like with any rental property, some of the profit should be saved to cover future needed repairs and maintenance in order to protect your investment. The key point with both land and stocks from a cash flow side is that, in order to realize and tap in to increases in equity, there has to be a sale of the asset that could trigger capital gains.

\section{Austin Duerfeldt is an agricultural economist and extension educator in the Department of Agricultural}

\section{Economics.}

